\begin{tabular}{|l|l|l|}
\hline \multicolumn{2}{|c|}{ PublisherInfo } \\
\hline \hline PublisherName & $:$ & BioMed Central \\
\hline \hline PublisherLocation & $:$ & London \\
\hline \hline PublisherImprintName & $:$ & BioMed Central \\
\hline \hline
\end{tabular}

\title{
The effect of BRK on EGF signalling via erbB3 in mammary epithelial cells
}

\begin{tabular}{||l|l|l||}
\hline \multicolumn{2}{|c||}{ ArticleInfo } \\
\hline \hline ArticleID & $:$ & 3759 \\
\hline \hline ArticleDOI & $:$ & $10.1186 /$ bcr-2001-66722 \\
\hline \hline ArticleCitationID & $:$ & 66722 \\
\hline \hline ArticleSequenceNumber & $:$ & 31 \\
\hline \hline ArticleCategory & $:$ & Paper Report \\
\hline ArticleFirstPage & $:$ & 1 \\
\hline \hline ArticleLastPage & $:$ & 4 \\
\hline \hline & & RegistrationDate : 2001-2-6 \\
ArticleHistory & $:$ & OnlineDate \\
\hline \hline ArticleCopyright & $:$ & Biomed Central Ltd2001 \\
\hline \hline ArticleGrants & $:$ & \\
\hline \hline ArticleContext & $:$ & 1305833 \\
\hline \hline
\end{tabular}


Jenny Gomm, ${ }^{\text {Affl }}$

Aff1 Trafford Centre, University of Sussex, UK

\section{Keywords}

Apoptosis, BRK, EGF, epithelial cells, erbB3, mammary, PI 3-kinase

\section{Introduction}

$\mathrm{BRK}$ is an intracellular protein-tyrosine kinase that is expressed in $60 \%$ of human breast cancers but is undetectable in normal and benign breast tissues. The introduction of the BRK gene into the normal breast epithelial cell lines HB4a and MCF10-A leads to a potentiation of their growth response to the mitogen EGF and their ability to proliferate in an anchorage-independent manner. BRK and the EGF receptor (EGFR) have also been shown to form a constitutive association in mammary epithelial cells.

\section{Aims}

To investigate how BRK influences EGF downstream signalling in human mammary epithelial cells.

\section{Comments}

The ability of breast receptor kinase (BRK) to deregulate cellular proliferation together with its expression in $60 \%$ of breast cancers and the documented importance of protein-tyrosine kinases in tumorigenesis makes this an important study. BRK is shown to provide a link between epidermal growth factor (EGF) binding to its receptor and the phosphorylation of erbB3 which leads to an increase in cell number, either by increased proliferation or decreased apoptosis. As erbB2 is thought to mediate in the activation of $e r b \mathrm{~B} 3$ and, as both of these receptors have been shown to be overexpressed in a proportion of breast cancers, further studies will be needed to determine the role of erbB2 in this BRK/erbB3 interaction. Also, does neu differentiation factor/heregulin, which is known to bind directly to erbB3 leading to both the recruitment of phosphoinositide (PI) 3-kinase's p85 subunit and increased mitogenesis, also interact with BRK? 


\section{Methods}

HB4a cells were transiently transfected with empty or brk expression vectors. Following overnight quiescence in $0.5 \% \mathrm{FCS}$, cells were treated with EGF $(100 \mathrm{ng} / \mathrm{ml})$ for 5 minutes. BRK or erbB3 was then immunoprecipitated from lysates of stimulated or mock-stimulated cells, resolved by SDS-PAGE, Western blotted and probed with antibodies to BRK, phosphotyrosine, erbB3, the p85 subunit of PI 3-kinase (PI 3-kinase p85) or Akt/protein kinase B (Akt). PI 3-kinase activity was assayed in erbB3 precipitates. BRK and erbB3 were also co-expressed in human embryonic kidney (HEK293) cells.

\section{Results}

Mock stimulated BRK transfected cells showed an increase in phosphorylation of erbB3 above control cells together with the recruitment of the PI 3-kinase p85. Treatment of BRK-transfected HB4a cells with EGF led to enhanced tyrosine phosphorylation of both BRK and erbB3 and an increased association of PI 3-kinase p85. In HEK293 kidney cells overexpressing both erbB3 and BRK, immunoprecipitation of $e r b \mathrm{~B} 3$ demonstrated not only enhanced phosphorylation but also the formation of $e r b \mathrm{~B} 3 / \mathrm{BRK}$ complexes. Mutant BRK, lacking kinase activity, failed to induce erbB3 phosphorylation but still co-precipitated with it. PI 3-kinase assays showed that there was an increase in enzyme activity associated with erbB3 in response to EGF in HB4a control cells. This increased twofold in BRKexpressing cells. A potential downstream target of PI 3-kinase, Akt, was also found to exhibit a low level of phosphorylation at serine 473 following EGF treatment of BRK-expressing cells. This is one of two sites whose phosphorylation is required for full activation of Akt.

\section{Discussion}

This study shows that the expression of BRK in human mammary epithelial cells significantly enhanced the degree to which erbB3 became phosphorylated in response to EGF. Results using the expression of a kinase inactive BRK mutant suggests that BRK may directly phosphorylate erbB3, possibly by physical interaction. The recruitment of the p85 subunit of PI 3-kinase, its increased activity and the phosphorylation of Akt are further evidence of a role for BRK in EGF downstream signalling. Thus the expression of BRK in human breast cancer cells could lead to a greater efficiency of mitogens such as EGF.

\section{Additional information}


Ignatoski KM, Lapointe, AJ, Radany, EH, Ethier SP: ErbB2 overexpression in human mammary epithelial cells confers growth factor independence. Endocrinology 1999, 140:3615-3622.

Orr MS, O'Connor PM, Kohn KW: Effects of c-erbB2 overexpression on the drug sensitivities of normal human mammary epithelial cells. J Natl Cancer Inst 2000, 92:987-994.

\section{References}

1. Kamalati T, Jolin HE, Fry MJ, Crompton MR: Expression of the BRK tyrosine kinase in mammary epithelial cells enhances the coupling of EGF signalling to PI 3-kinase and Akt, via erbB3 phosphorylation. Oncogene. 2001, 19: 5471-5476. 